UDC: $338.486 .22(477.85-25): 338.48-44(620)$

https://doi.org/10.17721/2308-13 $\underline{5 X .2020 .59 .45-50}$

Andrusiak Natalia Stepanivna,

PhD in Biology, Associate Professor Yuriy Fedkovych Chernivtsi National University, Buktravel Travel Agency, Chernivtsi, Ukraine, e-mail: n.andrusyak@chnu.edu.ua

Anipko Nataliia Petrivna,

PhD in Geography, Associate Professor Yuriy Fedkovych Chernivtsi National University, Buktravel Travel Agency, Chernivtsi, Ukraine, e-mail: n.anipko@chnu.edu.ua

Smyk Oksana Stepanovna,

Candidate Of Geographical Sciences Yuriy Fedkovych Chernivtsi National University, Chernivtsi, Ukraine,

e-mail: o.smuk@chnu.edu.ua 


\section{ANALYSIS OF TOURIST DEMAND CHERNIVTSI IN THE DIRECTION OF EGYPT IN 2020}

Purpose. Analyze the results of surveys of tourists who used the services of travel agencies in Chernivtsi in the direction of Egypt in the 2020 season and identify "weaknesses" and "strengths" in the activities of travel agencies.

Methods. On the basis of the compiled questionnaire, a survey of tourists and processing of survey results was conducted. Tourists who used the services of travel agencies in Chernivtsi in Egypt were involved in the survey. The research methods of computer technology, statistical, comparative, survey was used.

Results. The results of a survey of tourists who used the services of travel agencies in Chernivtsi in Egypt direction in season 2020 are analyzed. It is determined what factors influence the tourist's choice of travel agency, what sources of information about tourist products are crucial for the tourist's choice, the share of tourists lost by travel agencies who planned to use their services but refused, the reasons for refusing the services of the recommended agency, the reasons for choosing Egypt for vacation, analyzed how tourists assessed the quality and safety of travel services in Egypt in the pandemic year 2020. Insufficient knowledge of the manager about the tourist product, incomplete and uncertain answers to questions about the border crossing procedure, the list of laboratories where the PCR test result can be obtained and the information that should be in the test result form, insufficient given time for the tourist, the reluctance of the manager to work with the tourist.

Scientific novelty. A new survey of tourists was conducted, the results of the study were processed and further directions in the improvement and future development of travel agencies in Ukraine were identified (on the example of Chernivtsi).

Practical significance. The practical significance of the study is to use the results to critically analyze the activities of travel agencies, identify "weaknesses" and "strengths" in their activities and find new ways to develop and improve, in particular, why the question of choosing a tourist product and a travel agency remains problematic for tourists. 
Keywords: Egypt, tourist product, travel agencies, tourist, questionnaire.

Список використаних джерел/ References:

1. Abul-Azm, A.G. and M.Hassanein. "EIA in the tourism sector in Egypt." 24 IAIA Meeting. Vancouver: IAIA, 2003. - $248 \mathrm{p}$.

2. Republic of Egypt Country Strategy Paper 2000-2002 // Business, ECES //Working Paper № 147 - 2000. - P.43-52.

3. Egyptian Tourist Authority. "Gift of the Sun." The official site of the Egyptian Tourist Authority. 6 September 2008 - [Електронний ресурс]. - Режим доступу: http://www.egypt.travel/?flashinstalled=2

4. Goeldner, C.R., J.R. Ritchie and R.W. McIntosh. Tourism: principles, practices, philosophies. - New York: John Wiley and Sons, 2000.- 385 p.

5. International tourism, number of arrivals - Egypt, Arab Rep. [Електронний ресурс]. - Режим доступу: https://data.worldbank.org/indicator/ST.INT.ARVL?locations=EG

6. Massoud, N., Sakr H. and Sakr M. Tourism in Egypt: an unfinished MEA. - 2012. - 215 p.

7. The new territories of tourism in Egypt: a local-global frontier? //European Journal of Geography [Електронний ресурс]. - Режим доступу https://www.researchgate.net/publication/263226839_The_new_territories_of_tourism_in_Egypt _a_localglobal_frontier_Cybergeo_European_Journal_of_Geography_URL_httpcybergeorevues org23324 
8. Travel and Tourism in Egypt to 2018 [Електронний ресурс]. - Режим доступу https://www.marketresearch.com/product/sample-8015994.pdf

9. UNWTO World Tourism Barometr [Електронний ресурс]. - Режим доступу: http://mkt.unwto.org/barometer

Надійшла до редколегії 02.12.2020 